\title{
PATRIOTISM AND LOVE IN THE CONTEXT OF THE ESTONIAN WESTERN DIASPORA
}

\author{
Triinu Ojamaa \\ Estonian Literary Museum \\ e-mail: triinu.ojamaa@folklore.ee
}

\begin{abstract}
The article focuses on the love Estonians abroad have for their country of origin, compatriots, and people with different ethnic backgrounds. The research material consists of interviews, essays, and two novels. The interviews have mainly been collected from the Second World War refugees and their descendants in Canada, the USA, Australia, and Europe. The essays include immigrants' thoughts and feelings toward Estonia from the time of the restoration of the Republic of Estonia's independence onward. Elin Toona's novel Sipelgas sinise kausi all (The ant under the blue bowl) and Enn Nõu's novel Ma armastasin rootslast ehk Sollefteå suvi (I loved a Swede or summer in Sollefteå) are based on the authors' personal life experience in exile and reflect the refugees' attitudes toward Estonia as well as their host country. Based on the listed material, the article discusses the following issues: What are the sources of diaspora Estonians' patriotic feelings? How do the older diaspora generations teach the youth to love Estonia? Can the love for Estonia be unified with the love toward a non-Estonian?

The research revealed that the descendants of the refugees love Estonia as their ancestors' homeland and the source of cultural heritage. For those who have never lived in Estonia the country may take on the connotation of a fairytale land. Retelling of memoirs by older generations about their lives in Estonia before the Second World War has still an important role in generating a sense of patriotism toward Estonia. At the beginning of the exile period, literature also took on the role of supporting patriotic upbringing; later on this function waned.

The analyzed material points to changes in the attitudes of diaspora Estonians. During the post-war years, simultaneous love for Estonia and non-Estonians may have caused conflict situations as the general belief in the community was that mixed marriages threatened the sustainability of the Estonian diaspora. The younger generations as well as Estonians who left the homeland during the independence period starting from 1991 have a more multicultural attitude: they believe that mixed marriages and connectedness to some other culture do not limit their positive feelings toward Estonia.
\end{abstract}

Keywords: Estonia, Estonian Western diaspora, exile literature, love, mixed marriages, patriotism 


\section{INTRODUCTION}

The feelings of patriotism immigrants experience toward their host countries in Europe and elsewhere are coming into the realm of interest in diaspora studies. The rise of this issue is partially the result of escalating immigration problems encountered in the world today. For example, in their comparative study about host country patriotism among European immigrants, Tim Reeskens and Matthew Wright (2014) attempt to find out whether immigrants feel included or excluded in new situations and what contextual elements might influence them to express love and pride toward their host country. Qianqian Li's (2015) study on becoming American demonstrates how the applicants for naturalization learn American values and the reasons to be patriotic. Aune Valk, Kristel KaruKletter and Marianna Drozdova's (2011) study about Estonian open identity sets a goal to find the aspects of the Estonian national identity that would be acceptable to all ethnic groups in Estonia. The study also allows one to conclude which aspects Russian-speaking minority groups could use to build their own sense of Estonian patriotism and which aspects would serve as barriers.

In the current article I define patriotism as love of one's country and culture, identification with them, and special concern for their well-being as well as that of one's compatriots. In the context of the Estonian diaspora group, patriotism is connected to their ethnic identity. According to some authors, patriotism and loyalty can be regarded as synonymous. There undoubtedly exist certain ties between patriotism and loyalty. Nevertheless, in the current study I keep these two terms apart: I define loyalty as faithfulness to the state which is connected to one's civic identity. The current study passingly touches on the topic of loyalty; however, it focuses on diaspora Estonians' love for their country of origin (patriotism) and romantic love for compatriots and those of other ethnic backgrounds.

The article discusses the following issues: (1) What are the sources of diaspora Estonians' patriotic feelings? (2) How do the older diaspora generations teach the youth to love Estonia? (3) Can the love for Estonia be unified with the love toward a non-Estonian? These questions will not lose their relevance for as long as diaspora communities exist and develop, or at least until younger multicultural generations and new immigrants join them, whose attitudes toward their homeland have been developed on the basis of their own specific experiences. 


\section{RESEARCH MATERIAL AND METHOD}

The main research material consists of 52 semi-structured interviews which were conducted with representatives of the Estonian Western diaspora in Canada, USA, Australia, and Europe. The conversations with the interviewees took place in Estonian. The interviews were collected in 2008-2012 as part of the project "Perspectives of music in constructing the Estonian open identity". The collection has been supplemented with new interviews from 2014-2016, collected within the framework of the project "Formal and informal networks of literature based on sources of cultural history".

The interviewees are divided into two groups: the old-diaspora group (refugees of the Second World War and their descendants), and the new-diaspora group (Estonians who left the homeland at the end of the Soviet occupation or after the restoration of Estonia's independence in 1991).

The interviews touched on the following topics: What kind of relationship does the interviewee have with Estonia and Estonian culture (emphasis on music)? What are the criteria for being a "proper" Estonian? The main characteristics that seem to define a "proper" Estonian have been described by Triinu Ojamaa and Kristel Karu-Kletter (2014: 149): “A 'proper' Estonian is someone who speaks Estonian, feels he or she is Estonian, loves Estonia, has Estonian heritage, was born or lives in Estonia, shares a common history and culture with the other Estonians, is hard-working and loves music." The current article provides a more detailed analysis of the topic that arose from the interviews surrounding the opinions on how "proper" Estonians love Estonia.

As additional material, I used two collections and two novels that deal with topics similar to those of the semi-structured interviews. The collection Rändlindude pesad (The nests of migratory birds: Estonians' life stories abroad (Kirss 2006)) contains 12 life story interviews recorded with Estonians in Canada in 2000. The interviews include discussions about what it means to be an Estonian outside of Estonia. In the context of this article, these interviewees belong to the old-diaspora group. The collection titled Eesti ustest - sisse, välja (In and out of Estonia's doors: Speeches, articles, and essays (Käpp et al. 2013)) contains 14 essays collected during the Estonian President's literary collection campaign in 2011, 11 of which were written by people who had left Estonia and moved to the West after the restoration of Estonia's independence (in the context of the current article, they belong to the new-diaspora group). The authors of 3 essays represent the old-diaspora group. The essays describe the authors' attitudes toward Estonia and discuss the likelihood of their returning to their homeland.

The concept of generation used in this study is based on Karl Mannheim's work (1953 [1952]). In the context of the current article, a cohort who lives 
or has lived in similar conditions is considered a generation. They have experienced similar social changes and, as a result, certain similarities can be seen throughout their lives. The old-diaspora group began forming in the mid1940s and now includes three adult generations. The first generation consists of refugees who were born and received their education in Estonia; their views and attitudes have primarily been shaped within the surroundings of their original homeland. The second generation includes the children who traveled along with their refugee parents and those born in exile; they were raised and received their education outside of Estonia. The third generation includes the children of the second generation. The beliefs and attitudes of the second and third generations were shaped by the host country's sphere of influence.

For the analysis of the new-diaspora group, the focus is on the first generation. This group has existed for about 25 years and the second generation is just beginning to reach adulthood today. As in the old-diaspora first generation, the first generation of the new-diaspora group includes those who were born and received their education in Estonia, although in a different social-political context. However, the new-diaspora group's departure from Estonia has instead been voluntary (often for financial reasons) and therefore, less of a traumatic experience than the flight of the refugees.

All of the interviews and essay excerpts below have been given symbols: $\mathrm{O}=$ old-diaspora group; $\mathrm{N}$ = new-diaspora group; I, II, III = I, II or III diaspora generation respectively; $\mathrm{M}=$ male interviewee; $\mathrm{F}=$ female interviewee. In the collection Rändlindude pesad, Kirss (2006: 648) has criticized the three generations principle, in which the boundaries of the generations are based on being born in Estonia or in exile. In the analysis of the interviews, Kirss uses the term sillapõlvkond (bridging generation).

Those belonging to the bridging generation are exiles who, on the basis of having been born in Estonia could be considered part of the first generation, but who also, because of the fact that their views and attitudes were shaped in exile, could be regarded as connected with the second generation. For the purpose of comparing life stories interviews with those collected for the project "Perspectives of music in constructing the Estonian open identity", I have categorized the interview excerpts from Kirss' collection using my own system (i.e., the second generation includes the "bridging generation"). In fact, these alternative ways of distinguishing generations do not oppose one another, as both of the systems consider whether the interviewees' views and attitudes were shaped in the social-cultural environment of Estonia or the host country. I have used the same system of categorization when comparing the interviews from the collection Eesti ustest - sisse, välja. Quotes presented in this article 
originating from the abovementioned collection are differentiated from the other material with references.

Several problems occurring in diaspora community gave inspiration to Estonian exile writers. One can treat fiction as an indicator on its own: if a problem has been mentioned in a literary work, it could be deduced to have been a significant issue in the exile community. This article analyzes two novels: Elin Toona's Sipelgas sinise kausi all (The ant under the blue bowl) and Enn Nõu's Ma armastasin rootslast ehk Sollefteå suvi (I loved a Swede or summer in Sollefteå). Both novels are based on the exile authors' personal experience and reflect the relationships the refugees had with Estonia as well as the host country. In the context of the current study, both the authors and their characters represent the second generation of the old-diaspora group. The novels are similar by their main issue: the protagonists fall in love with non-Estonians and refuse to get married because the situation causes conflict between their romantic love and patriotic feelings.

\section{WHAT DOES IT MEAN - TO LOVE ESTONIA?}

Based on interviews, this section analyzes the essence of diaspora Estonians' patriotism and the ways they express their patriotic feelings. Approximately one third of the interviewees believed that a "proper" Estonian is someone who loves Estonia, thinks of Estonia often, and cares for the success and reputation of Estonia as a country, for example:

You are an Estonian if you love Estonia no matter how well you speak the language. Whenever you hear the word "Eesti", you prick up your ears and wonder what that person will say about it. If they speak poorly of Estonia, then, if they are acquaintances, you may keep your thoughts to yourself and curse them in your mind; however, if they are strangers, then you jump right in and defend Estonia fervently. (O-II-F, Canada)

In the course of the analysis, two interesting aspects were revealed. Firstly, only the representatives of the second and third generations of the old-diaspora group discussed their love for Estonia. This is intriguing because these generations were raised or born outside of Estonia. They have visited Estonia but have never lived in the country they love. Secondly, it emerged from the interviews that those who love Estonia often describe it as a fairy-tale land. These observations lead me to wonder how the love for a country such as Estonia, almost unknown to these generations, has emerged and developed. Based on a number of previous studies (e.g. Kiviloog 1978; Aun 1985), one can say that the first generation 
of the old-diaspora group made an attempt to raise the second generation to be Estonians - scouts' and girl guides' organizations, supplementary schools and church congregations played a significant role in achieving this goal. The interviews demonstrate that the positive positions parents held toward Estonia also had a strong influence:

We were raised speaking Estonian and remembering Estonia. (O-II-M, Australia/USA) (Kirss 2006: 566)

Father and mother were of the same mind and believed that we should be raised as Estonians and keep the English-speaking world at a certain distance. (O-II-M, Australia/USA) (ibid.: 571)

The interviews also revealed that the second and third generations feel a strong sense of belonging to the culture that constantly surrounds them in school or at the workplace in the host country. However, their contact with the heritage culture is realized in a special manner:

Being an Estonian was special, ceremonial, a Sunday honour, which became invisible when Monday evening came around. On Sundays we memorized Visnapuu ${ }^{1}$ and Liiv ${ }^{2}$, but on Mondays they were replaced by Shakespeare and Jean Racine. (Kirss 2008: 249)

"Raising an Estonian" in such cultural circumstances (living in two cultures simultaneously) could either be successful or unsuccessful. Constant pressure to feel patriotic could result in pushing youth away from their ethnic culture (Rakfeldt 1978: 29). In contrast, having the freedom to choose one's cultural belonging often worked in favor of the preservation of Estonian culture (Rand 1978: 84). It can be deduced from our interviews that the parents' "gentle directional urge" usually led the interviewees to develop a feeling of love for Estonia. The common term for this feeling is patriotism; however, not a single interviewee used this word to describe their feelings. It is interesting to note that when speaking of Estonia, the interviewees always spoke of love, whereas when speaking about their host country, they spoke of loyalty instead. A number of interviewees clearly defined and separated their feelings for each country:

Being an Estonian is two things: either it is a thing of the heart or a thing of the mind. Those people who lived their entire life in another country can only be Estonian at heart, while logically speaking they are loyal citizens of the host country. (O-II-F, Australia)

The third generation respondents often had very emotional responses, which indicated that Estonia is just a special place that should be loved unconditionally. "I love it! It is extremely important to me!" - this is a teenage boy's description 
of his relationship with Estonia as an Estonian-Canadian who does not speak Estonian (Ojamaa \& Valk 2008: 68).

\section{ESTONIA AS A FAIRY-TALE LAND}

The interviewees who feel love for Estonia often describe the country as a fairytale land. The following interview excerpts demonstrate that the emergence of such an image has been influenced by the stories of pre-war Estonia told by the older generation.

In childhood it did seem like a fairy-tale land. [---] When we spent time with our relatives, we heard their stories about how life in Estonia used to be [before going into exile in 1944]. We remember mainly good things. There of course were some difficulties, but it was still some kind of golden age. That is why it was like a fairy tale. (O-II-M, USA)

In her essay "Muinasjutust saab argielu" (A fairy tale becomes everyday life (Käpp et al. 2013: 211-215)), Marika Kristi Ets describes an excellent story of how love for Estonia can be initiated and how it can change over time. Her grandmother (first generation) can be regarded as the source of love. She told stories about the homeland, disposing her grandchild's early positive attitude toward the country which she only saw for the first time as a university student.

Moving to Estonia as an Estonian from abroad is like falling into a fairytale. You have heard about this place for your whole life, have sung about it, seen photos, so when you finally see the tiny sprat tin silhouette of Tallinn, you can hardly believe that you aren't in a dream. (O-III-F, USA) (Käpp et al. 2013: 211)

Estonians call the view of Tallinn from the sea, where the church spires and castle towers line the skyline, the "sprat tin silhouette". The silhouette became a visual symbol of Estonia already before the Second World War; it was used on the packaging of various products, including sprat tins. The notion "sprat tin silhouette" has had an important role in shaping the image of Estonia. Refugees took photos of the silhouette; later some artists in exile reimagined the silhouette in paintings and leatherwork, which can be found in the homes of diaspora Estonians all over the world. ${ }^{3}$ Thus, the towers of Tallinn have become an important symbol even for those who have never been to Estonia. The diaspora Estonians who on their first trip to Estonia arrived in Tallinn by sea, experienced at first hand how their prior visions met with reality. Many 
interviewees described this experience with positive emotions that they would never forget:

When I traveled to Tallinn for the first time in 1974, I was on the boat from Helsinki and I saw the towers of Tallinn in the distance and then it really was like - oh, there it is! It was such an experience to know that it really does exist! (O-II-M, USA)

In the following interview excerpt, the interviewee describes the arrival of the Toronto Estonian Supplementary School Choir in Tallinn for the 2004 Song Festival:

We flew to Helsinki by plane and went on from there on a ship. All the children did not fit onto the flight to Tallinn. But there was one other thing. We were able to see how Estonia... rose out of the sea, all those towers, which the children already knew about from their geography lessons. And they kept coming closer and closer... it was a big deal for the children. ${ }^{4}$ (O-II-F, Canada)

Symbolically, approaching Estonia by sea is like a journey backwards, compared to the flight of the older generation in 1944. Many refugees fled by sea, watching with heartache the coastline fade in the distance. Although the second and third generations have never fled the country, the interviews showed that they felt their arrival in Estonia as if they were returning.

When a direct encounter with the real Estonia occurs, it may draw a veil over the fairy-tale land image. Second generation interviewees, who had visited Estonia in the 1970s, felt some disappointment already during their first few days in the country.

[---] I had attended Toronto Estonian Supplementary School and was a scout and spoke Estonian at home, but Estonia really was a fairy-tale land. [---] My main impression of Estonia was that everything is very grey. (O-II-M, Canada) (Kirss 2006: 589)

The abovementioned O-II-M with an American background, who enthusiastically described the moment he saw the towers of Tallinn, continues his memories of his first encounter with Estonia:

Upon arriving in Estonia, the reality was harsh. The visit took place under the watchful eye of a $K G B^{5}$ officer, as is the practice in a totalitarian country, and it did not match the image of a fairy-tale land at all. (O-II-M, USA) 
Marika Kristi Ets (O-III-F) came to Estonia 30 years later than O-II-M. During that time, Estonia had been freed from the Soviet occupation and economy began to develop quickly. Estonia was no longer as grey and dirty and the KGB had finished its activity. Despite all this, her imagination of a fairy-tale land receded after some time:

Estonia does not seem to be a fairy-tale land to me anymore. It is now a real place with good and bad aspects. It is also my home. [---] I don't idealize Estonia anymore because I feel that I know this country more intimately now. [---] I know how cold the winters are and I know the stresses of everyday life. (O-III-F, USA) (Käpp et al. 2013: 213-214)

The last excerpt shows how the consequences of the collision of the two worlds imaginary and real Estonia - do not necessarily mean that the emotional value of the country is lost. One can still love the country despite its faults.

In the course of the analysis it became apparent that (1) the older generation's memories of life in Estonia supported the development of the younger generation's sense of patriotism; (2) some descendants of refugees, who did not have personal memories of Estonia, began to imagine Estonia as a fairy-tale land; (3) the younger generations felt the need to see the "fairy-tale land" with their own eyes and experience the immediacy of their ethno-cultural roots.

\section{FROM ILLUSIONS TO REALITY}

While examining the abovementioned conclusions in a wider context of diaspora discourse, one can say that they are not specific to Estonia. The older generation's creation of an embellished image of their country of origin, based on their memories, is a common characteristic in many diaspora communities. For example, in his study about Chinese American immigrants, Jean Amato (2015: 431) writes that "from the late 1950 s to the late 1970 s, internal political and social turmoil in China [---] and the larger international framework of the Cold War made almost all forms of contacts or visits to family members in mainland China untenable for Chinese Americans. [---] Thus, many Chinese Americans knew little about everyday life in the PRC, the state of their ancestral homes [---]. As a result, they could only look to tales of an ancestral home/homeland through the belated personal or familial legacy of memories [---]".

Another comparative example is connected with Prussian refugees. Similar to Estonians, the Prussians fled from the Soviet Army when the latter invaded Prussia in 1945. Most of the refugees settled in Germany and could not return to their former places of residence. What makes the Prussian case interesting 
is the fact that in the German Democratic Republic "it was dangerous for the Prussian expellees to express their attachment to their old homeland: they were afraid of their children's behavior. Children could easily say something that went against the grain of the official position, and this might have consequences for the whole family. So it happened frequently that the adults chose to lower their voice or that they completely avoided talking about the old home in the presence of their children" (Bierwerth 2015: 172).

The Prussian refugees' situation differed from that of the Estonian refugees, as Estonians lived in a free world and could openly remember their country of origin. Bierwerth's study shows that, despite the danger, Prussian refugees still shared their stories and memories of their homeland with their children. As a result, in the 1980s "return tourism" became popular; young people of Prussian origin began to visit their country of origin in masses. What they hoped to experience was slightly similar to Estonians' desire to visit the fairy-tale land: "The younger ones, those who know your places of origin mostly from their parents' reports, they say: Well, I want [---] to go and see what the sky looks like over there, or pick a flower, and so on" (ibid.: 179).

In some approaches, the myth of return holds an important place in the criteria of a diaspora community. According to William Safran (1991: 83-84), the shared hope of a return to the homeland creates a connection between the members of the diaspora community. Safran also finds that for a variety of reasons, in reality diaspora group members do not return to the homeland permanently "because there is no homeland to which to return; because, although a homeland may exist, it is not a welcoming place with which they can identify politically, ideologically, or socially; or because it would be too inconvenient and disruptive, if not traumatic, to leave the diaspora" (ibid.: 91). With reference to Avtar Brah's study, Kläger and Stierstorfer (2015: 3) demonstrate that in the diaspora context "home is a place of no return, even if it is possible to visit the place of origin. Nevertheless, members of the diaspora groups can be characterized by having a craving for home as a "mythic place".

With regard to the Estonian diaspora community, the intent to return to the homeland was widespread at the beginning of the life in exile, as the refugees believed their life abroad was only a short-term absence from the homeland. Cultural and political circles in exile made plans to continue their cultural and educational lives in Estonia after their expected return; the Culture Commission of the Estonian National Council in Sweden even published the programmatic document titled Eesti kultuurpoliitika sihtjooni: Juhtmõtteid eesti kultuuri taastamiseks vabal kodumaal (The goals of Estonian cultural politics: Thoughts on restoring Estonian culture in the free homeland (Tauli 1953)). However, the Cold War and the consequent political developments clearly indicated that return- 
ing was unrealistic. In addition, their ancestors' land was no longer considered home to the generation raised abroad. It was rather considered to be the origin of their roots, which - although important - one could survive without. Still, the wish of the older generation to return did not disappear without a trace. Over time, the strong desire to return was reduced to the myth of returning, which later became realized in the form of return tourism. According to Rakfeldt's (2015: 517) study based on material collected in 1991, "the most powerful predictor of Estonian identity was having visited Estonia [---]. Fifty-eight percent of participants had visited Estonia and, of these, $86 \%$ felt that the visit had definitely strengthened their Estonian identity. [---] The act of visiting Estonia had provided a powerful experience that evoked strong emotions".

Our interviews and essays revealed that the illusion of Estonia as a fairy-tale land did not coincide with reality. Several studies have shown that an idealization of the ancestral home is a common tendency of diaspora communities. They often "fabulate highly romantic fantasies of the 'old country' beginning with the Jews' 'promised land' flowing with milk and honey" (Cohen 1997: 185). Studies conducted in the 2000s about other diaspora communities have continually confirmed that the gap between fantasy and reality can be deep and cause disappointment. The above-mentioned study about Chinese Americans includes several examples of the reactions the Chinese had when they visited their country of origin, for instance, "Everything is poor! The country is poor! [---] The communists have ruined everything!" Amato concludes, "Nostalgic love can only survive in a long distance relationship" (Amato 2015: 437).

\section{TEACHING PATRIOTISM}

The new-diaspora group is not as sentimental toward Estonia as the old-diaspora group. In interviews and essays they discuss what is wrong in Estonia and what should be changed in order for anyone to want to return and live there. Based on our material, the new-diaspora group could be characterized as a group that is affected by the fate of the homeland, but that does not feel the desire to return. Thus, the new-diaspora group is missing one of the characteristics that Safran considered an important part of the diaspora experience. Loving Estonia and its fairytaleness seem not to be an important topic for the new-diaspora group. Only one interviewee mentioned the fairy-tale land, in the context of explaining the differences between the old-diaspora and new-diaspora groups:

Here, yes, it is like a fairy-tale land to them [the old-diaspora group], where everything is without fault, where the air smells like strawberries and fresh birch, the fields are beautiful and the sun is always shining; 
there is never any mud anywhere. Nevertheless, we all know that in reality it is not always like this. (N-I-F, Sweden)

New-diaspora group members have left voluntarily and for two main reasons: to study or to work. Many of them are economic immigrants, who hope to earn a better income and live in better conditions in another country. Estonians have been migrating for similar reasons since the nineteenth century, the main destination countries being Australia, South and North America, and Canada. Earlier studies show that when comparing political refugees who fled during the Second World War, voluntary (economic) migrants have a weaker sense of ethnic self-identification and an almost non-existent sense of patriotism (Pennar \& Parming \& Rebane 1975: vii-ix, 85; Salasoo 1986: 127). Other sources show that the attitudes the economic immigrants have toward Estonia have not always been homogenous. Some immigrants attempted to assimilate quickly, as this helped them be successful in the labor market. In contrast, others found that preserving ties with their heritage culture was important. This opinion is supported by the fact that economic immigrants established some of the first Estonian cultural societies in Canada and Australia at the beginning of the twentieth century (Kurlents \& Antik \& Olvet 1975: 34; Barrow 2012: 3). Many new-diaspora group members have also joined old Estonian organizations, which demonstrate that the connection to Estonian culture is still important to them.

In interviews, the new-diaspora group members do not talk about whether or how they love Estonia; yet, it is interesting that they do discuss how to pass the love for Estonia on to their children.

I would even say that it is better [to be] a second generation Estonian living abroad, who loves Estonia (and we believe, of course, that we are able to raise our children to love Estonia), than a native Estonian, who feels worse at home than anywhere else. (N-I-F, Finland) (Käpp et al. 2013: 251)

When we compare the first generations of the new-diaspora and old-diaspora groups, it becomes evident that they behave similarly - they begin to teach love for Estonia to their descendants who do not have immediate contact or have a weak connection with Estonia. In their future plans, their children will become the second generation of the new-diaspora group. They are preparing their children for life outside of Estonia, at the same time trying to preserve the awareness of their Estonian roots.

The interviews and essays show that in addition to retelling memories, speaking the Estonian language is very important. Language and love are inseparable according to all generations of the various waves of migration:

My contribution is also passing on the Estonian language to my children and together with it love for Estonia. (N-I-F, Germany) (Käpp et al. 2013: 252) 
Both the old-diaspora and new-diaspora interviewees believed music (song festivals and Estonian pop music) and visiting Estonia (especially participating in a song festival) to be important elements associated with loving Estonia. Only one interviewee discussed the role of literature. The older generation believes that young Estonians do not read books; thus, they are unable to influence their relationship with Estonia. Leelo Keevallik's study on Swedish-Estonian identity also confirms this opinion: "They wear national costumes to Independence Day ceremonies and subscribe to the Estonian-language newspaper, but reading Estonian literature is reported to be difficult by many of them" (Keevallik 2010: 181-182).

In the first decades of the exile period the circumstances were different from today. Literature in the language of origin belonged on the list of important identity markers, which the first generation attempted to use as a tool to cultivate patriotism in younger generations. In the document titled "Aims of Estonian cultural policy in exile", leading cultural-political figures emphasize:

The preservation of its youth for the Estonian nation demands more care than hitherto, not only from the refugee organizations and cultural and educational leaders, but also from all the refugees individually, more particularly from Estonian families. Special care must be taken that young people read Estonian literature [---]. (Estonian National Council 1956: 9)

There were a number of well-known writers among the refugees and in the 1940-50s, several publishing houses were established with the focus on actively dispersing Estonian literature outside of Estonia. Allegedly, by the end of 1945, 160,000 Estonian books had been published in Sweden (Horm 1946: 21). Our interviewees spoke with pride of how, in the context of their host country, the homes of Estonians drew attention with the large numbers of books they housed. As to be expected, most of the authors in exile wrote about life in Estonia. Arvo Mägi' (1968: 34) characterizes exile literature as "epoch literature", as it focuses on specific periods in Estonian history. Many authors have situated their novels in the pre-war period. Most often the activities take place at a safe cottage surrounded by beautiful nature, where days are filled with satisfying work. Such books had the potential of supporting the myth of the fairy-tale land. A significantly smaller number of novels touch on the exile period (Kangur \& Muru \& Tonts 1991: 7). The activities in these novels often take place in a big city, where characters of Estonian origin encounter other ethnic groups forcing them to communicate in a foreign language. Several problems arise in connection to ethnic identity and patriotism, as well as the lack of a sense of security and an unfulfilled need for an intimate closeness with other people. 


\section{PATRIOTIC FEELINGS VS ROMANTIC FEELINGS}

According to Tõnu Parming's (1978: 4) opinion, the older generation expected exile literature to generate a sense of ethnic belonging and patriotism among Estonians. He argues that the novels and poetry were lacking in relationships reflecting romantic or intimate love and rather were dominated by love for Estonia. In his essay "Eros ja Esto" (Eros and Estonianness), Parming (1979: 51) writes that the novels by exile authors directed young Estonians to communicate with each other as compatriots; thus, pushing gender roles in the background, which further contributed to the formation of mixed marriages. Parming concludes that exile literature produced Estonianism, but simultaneously inhibited the "production of new Estonians". Our interviews consist of examples that both confirm and contradict Parming's viewpoints; for example, an interviewee describes his Estonian friends in Sydney:

There were relationships and crushes, but if you were to look at who found themselves a partner, then many had outside marriages. Relationships within the group developed into mutual friendships. (O-II-M, Australia/ USA) (Kirss 2006: 577)

An O-II-M found himself an American girlfriend while living in the USA, but after some time he had to leave her behind:

It was my first serious relationship with a non-Estonian. [---] We went to Australia too. It was not a good experience. I remember we visited my grandfather and speaking English in his house was a grim event. Soon after, our relationship ended. (Kirss 2006: 581)

An O-II-M married an Estonian. The following example comes from his Swedish generation-mate, although this story ended with a mixed marriage:

There was a boy. He did not live in Stockholm, but when there was an Estonian party or something, he stayed the night at our house, in my room. But no, I did not ever think that... He was like a brother to me! (O-II-F, Sweden)

An O-II-F came from an Estonian-minded home; she married a compatriot whom she met away from home, in Canada. The couple made the effort to tie their marriage to "Estonian life", but the husband was not interested in Estonian social life, and the marriage resulted in divorce. The interviewee returned to Sweden and married a Swede. She is still married and also an active member in the Estonian-Swedish diaspora community. This case demonstrates that love for a Swede does not necessarily prevent love for Estonia or vice versa. 
Inspired by Parming's perspectives and based on the interviews, we could look for the impact literature had on real life. Based on the interviews, we can conclude that the youth did not use literature as an example when choosing a partner in marriage, whether they married an Estonian or someone else. However, one can agree with Parming that the attempt to generate patriotism is clearly perceptible in fiction written by authors of the old-diaspora first generation. The role of literature and writers as the supporters and promoters of ethnic identity is considered important also in many other diaspora communities. According to Anteby-Yemini \& Berthomière (2005: 265), "most of the leaders of a diaspora community were (and still tend to be) intellectuals, writers, very active in the public sphere".

Over time, Estonian exile literature became more critical of the uncompromising demands for Estonianism. In the mid-1960s, the second generation of the old-diaspora entered literature. The conflict between patriotism and choosing the right partner in marriage became one of the more pointed problems in their work.

Two excellent examples of this are Elin Toona's ${ }^{7}$ novel Sipelgas sinise kausi all (The ant under the blue bowl, 1974) and Enn Nõu's ${ }^{8}$ novel Ma armastasin rootslast ehk Sollefteå suvi (I loved a Swede or summer in Sollefteå, 2013). The novels are set in the 1950s-60s. Both of the protagonists - Ants Karusoja in the first novel and Eerik Neier in the second one - are the authors' peers. They live their life in exile, in the same countries as the authors (England and Sweden). Both protagonists were raised in families that respected Estonian traditions. They keep their distance from other ethnic groups in order to preserve their Estonianness, and only minimally participate in the culture of their host country. Both protagonists wish to marry, but are unable to find a suitable partner from among their compatriots. Ants Karusoja begins to develop an intimate relationship with an Englishwoman Pauline Lovejoy, and Eerik Neier with a Swede Ingalill Stormare. In both cases, the protagonists end the relationships because of their strong patriotic feelings.

In the novel Ma armastasin rootslast ehk Solleftea suvi (I loved a Swede or summer in Sollefteå) the plot begins in the summer of 1955, when the protagonist Eerik is serving in the Swedish army. In this situation it is important to notice a hint at the loyalty the Estonian refugees felt towards the country that had granted them asylum. Our interviews reveal that loyalty is also a strong characteristic of the second generation. However, loyalty is not Nõu's main theme; he focuses on the love story between an Estonian refugee and the daughter of a Swedish officer. Nõu clearly directs attention to the problems faced by those of marriageable age in the second generation, to which they had to find answers in reality: What kind of love is the "right" love? How does 
Estonianness relate to marriage or would mixed marriage be acceptable in the exile community?

In reality, members of the older generation believed that an Estonian man should find an Estonian girl to marry; this is also postulated in the novel (see Nõu 2013: 99). The author's tone is neutral; thus, it is difficult to determine whether he himself shares the stance of the older generation or not. One can only state that the author ends the protagonist's love story in the early stages, with his surrender to the nationalist principle:

Inevitably, the conflict of Estonian vs. Swedish had to arise sooner or later; it was engrained from the beginning and is a high price to pay for a fanatic nationalist. [---] In the interests of the Holy Estonian people, one is forced to act in this way, to place love on the altar as a sacrifice to the homeland. (Nõu 2013: 210)

The protagonist of Toona's novel, Ants Karusoja, comes to the conclusion - after weighing the pros and cons - that marrying an English woman would mean removing the Estonian language, food, and other traditions from his everyday life. A mixed marriage would be "crossing over from one national culture to another" (Toona 1974: 228); it would be a betrayal of Estonianness. The protagonist quickly leaves the meeting place where his English love was soon to arrive, rushing home to where a rich Estonian Christmas lunch awaits him.

Both authors have placed their protagonists in doubtful positions. Their decisions to end their relationships were not easy and they were not entirely convinced that they had made the right choice. One important question to raise doubt is what love means. Toona demonstrates in multiple episodes that linguistic miscommunication and many cultural misunderstandings can occur between the Estonians and the English, also in matters of love. Ants Karusoja reflects: "In Estonian the word 'love' has only one absolute meaning. In English, however, it can have many." (Toona 1974: 217)

But what does it mean exactly? In her novel, Toona does not unpack the ethno-cultural aspects of love. In this sense, Nõu's novel is more informative; he uses the term "Estonian-like love" (2013: 103), which means that romantic love must also include a nationalist component (i.e. patriotism). Eerik Neier does not believe it is possible to love a Swede and Estonia simultaneously.

The critic Meelas Karutald (2014: 28) writes that in Eerik's case the reader today could see the consequences of poor integration politics. I believe that both Nõu's and Toona's novels reflect the natural process of integration in an excellent manner, including all the positive and negative developments. The novels exemplify how the refugees wished for the dominant group to accept them, but also how they did not want to abandon any of their nationalist ideas or cultural heritage. 
It is interesting that both authors have shown that, in comparison with the refugees, the level of integration readiness is much higher among the dominant group. For example, Pauline would have happily married Ants despite his ethnic affiliation, different food, and other traditions. Ingalill was even ready to learn Estonian to be acceptable as a wife for Eerik. However, neither of the female characters could have fully shared Estonian heritage, love and loyalty for the country with their husbands, which at the beginning of exile period was the deciding factor in the eyes of the older generation.

\section{CONCLUSION}

The interview-based studies on diaspora often include examples in which the interviewees express their nostalgic and patriotic feelings toward their country of origin. The Estonian material reveals that the representatives of various groups (refugees and voluntary immigrants or new and old diaspora) describe their feelings differently. The new-diaspora group which began to develop in the early 1990s consists mainly of economic immigrants. In comparison to refugees they are more critical of the living conditions in Estonia, though not indifferent to its future. The members of the old-diaspora group mostly speak about their interest in Estonia's development, their pride, and sometimes their heartache for Estonia. A much smaller part of interviewees summarized their attitudes and feelings toward Estonia with the word "love". However, when analyzing the interviews, discussions about love for Estonia came to my attention; the topic frequently arose in the interviews with old-diaspora second and third generation members who had been raised and/or born outside of Estonia.

The second and third generation diaspora-Estonians are bicultural; thus, they share their patriotism between two countries. It is interesting that patriotism towards different countries can spring for different reasons. For example, immigrants who feel love or loyalty for the United States of America associate the country with freedom and justice, which are also the country's most important core values in official discourses. In addition, our interviews revealed that loyalty for a host country is inseparable from the gratitude the refugees feel for receiving help after the Second World War. Diaspora-Estonians love Estonia for a very different reason: it is the country of their ancestors and the source of their cultural heritage, in addition to having the connotation of a fairy-tale land.

The second and third generation of the old-diaspora group have been raised abroad; thus, they do not have any personal experience of Estonia. Estonian supplementary school and youth organizations have purposely shaped their attitudes. Studies on diaspora communities of various ethnic backgrounds have 
shown that, when teaching love for the ancestral homeland, the universal tool is retelling memories to the younger generations. This tool also fits well in the context of the Estonian Western diaspora. For Estonians, important tools for raising patriotism are also speaking Estonian (language of origin is regarded one of the main identity markers for Estonians) and a connection to the Estonian music culture (Estonians call themselves a "singing nation").

With regard to romantic love, the analyzed material reflects changes in the attitudes of diaspora Estonians. In the first decades of the exile period, the discussions in the diaspora community surrounding the "right love" or "Estonian kind of love" and the attitude toward mixed marriages was negative, as it was seen as a threat to the preservation of Estonian identity.

The members of the third generation are more open about their decisions: they do not speak about loving Estonia or Estonians as an obligation. The interviews reveal that the second generation consciously tried to avoid putting pressure on their children to love Estonia in a certain way, as they had experienced the pressure in their own childhood. Many members of the newdiaspora group are married to non-Estonians, in which case mixed marriage is more of an everyday reality than a complicated problem. The third generation of the old-diaspora group and the first generation of the new-diaspora group are similar in their views on multiculturalism. They believe that no matter what kind of connection they may have with other cultures, it will threaten neither their being Estonian nor their positive feelings toward Estonia.

\section{ACKNOWLEDGEMENTS}

Research for this article was supported by the Centre of Excellence in Estonian Studies (CEES, European Regional Development Fund) and is related to research project IUT 22-2 (Estonian Research Council). The author wishes to thank the anonymous reviewers for the valuable comments. 


\section{NOTES}

1 Henrik Visnapuu, Estonian poet (born in Estonia in 1890, died in the USA in 1951).

2 Juhan Liiv, Estonian poet (1864-1913) (born and died in Estonia).

${ }^{3}$ For a more detailed overview of symbols and other designed elements that represent ethnic identity in the diaspora Estonians' homes see Kõiva 2007: 57-61.

4 To read more about the emotions Canadian-Estonian teenagers experienced while traveling see Ojamaa 2011: 292-299.

5 The Committee for State Security was active in Estonia from 1954-1991.

${ }^{6}$ Arvo Mägi (born in Estonia in 1913, died in Sweden in 2004), Estonian author and journalist.

7 Elin Toona was born in Estonia in 1937. She fled to Germany in 1944, continued to England in 1947, where she studied at a theatre school. She currently lives in the USA. She became known as a writer in 1964.

8 Enn Nõu was born in Estonia in 1933. He fled to Sweden in 1944, where he graduated from the medical program at Uppsala University. He became known as a writer in 1968 .

\section{REFERENCES}

Amato, Jean 2015. It All Depends on What You Mean by Home: Metaphors of Return in Chinese American Travel Memoirs from the 1980s to 2010s. In: Florian Kläger \& Klaus Stierstorfer (eds.) Diasporic Constructions of Home and Belonging. Berlin \& Boston: De Gruyter, pp. 427-446.

Anteby-Yemini, Lisa \& Berthomière, William 2005. Diaspora: A Look Back on a Concept. Bulletin du Centre de recherche français à Jérusalem, Vol. 16, pp. 262-270. Available at http://journals.openedition.org/bcrfj/257, last accessed on 15 July 2019.

Aun, Karl 1985. The Political Refugees: A History of the Estonians in Canada. Toronto: McClelland and Stewart Ltd.

Barrow, Maie 2012. Estonians in Australia. Adelaide: Council of Estonian Societies in Australia.

Bierwerth, Gesa 2015. The Process of Integration among German Expellees in the GDR. In: Florian Kläger \& Klaus Stierstorfer (eds.) Diasporic Constructions of Home and Belonging. Berlin \& Boston: De Gruyter, pp. 163-182.

Cohen, Robin 1997. Global Diasporas: An Introduction. Seattle: University of Washington Press.

Estonian National Council 1956 = Estonian Culture in Exile: 10 Years of Estonian Cultural Activities in Sweden. Aims of Estonian Cultural Policy in Exile. Outlines of Estonian Cultural Policy. Estonian National Council Publication No. 7. Stockholm: Estonian National Council. 
Horm, Arvo 1946. Meie ja maailm: meie kultuurpropaganda - unustatud vaeslaps. [We and the World: Our Cultural Propaganda - a Forgotten Orphan.] Kodukolle, No. 7/8, pp. 21-23.

Kangur, Piret \& Muru, Karl \& Tonts, Ülo 1991. Väliseesti kirjandus. [Estonian Exile Literature.] Tallinn: Eesti Raamat.

Käpp, Triin \& Parder, Mari-Liisa \& Pisuke-Roos, Triin \& Sutrop, Margit \& Volberg, Mats (comps. \& eds.) 2013. Eesti ustest - sisse, välja: kõned, artiklid, esseed. [In and Out of Estonia's Doors: Speeches, Articles, and Essays.] Tartu: Eesti Keele Sihtasutus.

Karutald, Meelas 2014. Kaks sinimustvalget romaani. [Two Blue-Black-White Novels.] Sirp, 24 January, p. 28. Available at http://www.sirp.ee/s1-artiklid/c7-kirjandus/ kaks-sinimustvalget-romaani/, last accessed on 28 March 2018.

Keevallik, Leelo 2010. Everyday Construction of Identity in the Estonian Refugee Community in Sweden. Journal of Baltic Studies, Vol. 41, No. 2, pp. 177-200. http:// dx.doi.org/10.1080/01629771003731705.

Kirss, Tiina (comp.) 2006. Rändlindude pesad: Eestlaste elulood võõrsil. [The Nests of Migratory Birds: Estonians' Life Stories Abroad.] Tartu: Eesti Kirjandusmuuseum \& Toronto Ülikooli Eesti õppetool.

Kirss, Tiina 2008. Väärtustest ja eestluse tulevikust. [About Values and Future of Estonianness.] Akadeemia, Vol. 2 (227), pp. 236-256. Available at http://www. akad.ee/wp/2008/02/10/akadeemia-nr-2-2008/, last accessed on 29 March 2018.

Kiviloog, Helena 1978. Missuguseks eestlaseks? [To What Kind of Estonian?] In: Aja Kiri, No. 4, pp. 37-44.

Kläger, Florian \& Stierstorfer, Klaus 2015. Introduction. In: Florian Kläger \& Klaus Stierstorfer (eds.) Diasporic Constructions of Home and Belonging. Berlin \& Boston: De Gruyter, pp. 1-7.

Kõiva, Mare 2007. Austraaliaeestlased: migratsioon, kohesioon ja ruumimudelid. [Estonians in Australia: Migration, Cohesion, and Spatial Models.] In: M. Kõiva (comp.) Paar sammukest XXIII: Eesti Kirjandusmuuseumi aastaraamat. Tartu: EKM Teaduskirjastus, pp. 33-70. Available at http://www.folklore.ee/rl/pubte/ ee/araamat/2007/2marekoiva.pdf, last accessed on 29 March 2018.

Kurlents, Alfred \& Antik, Richard \& Olvet, Jaan 1975. Eestlased Kanadas: Ajalooline koguteos. [Estonians in Canada: Historical Collection.] Vol. 1. Toronto: Kanada Eestlaste Ajaloo Komisjon.

Mannheim, Karl 1953 [1952]. Essays on Sociology and Social Psychology. London: Routledge \& Kegan Paul. Available at https://archive.org/stream/ essaysonsociolog00mann\#page/n7/mode/2up, last accessed on 29 March 2018.

Mägi, Arvo 1968. Eesti pagulasproosa Rootsis ajapeeglina. [Refugee Prose by Estonians in Sweden as a Mirror of Time.] In: M. Üürike (ed.) Eesti Päevad Stokholmis 4.15. mail 1968. Eesti Päevade üldkava. Artikleid eestlaste kultuurilisest tegevusest. Stockholm: Eesti Kultuuri Koondis Stockholmis, pp. 34-47.

Nõu, Enn 2013. Ma armastasin rootslast ehk Sollefteå suvi. [I Loved a Swede or Summer in Sollefteå.] Tallinn: Tänapäev.

Ojamaa, Triinu 2011. 60 aastat eesti koorilaulu multikultuurses Torontos. [60 Years of Estonian Choral Singing in Multicultural Toronto.] Tartu: Eesti Kirjandusmuuseumi Teaduskirjastus. 
Ojamaa, Triinu \& Karu-Kletter, Kristel 2014. Diasporaa-eestlaste enesekuvand muutuvas maailmas. [The Self-Image of Diaspora Estonians in the Changing World.] Methis: Studia humaniora Estonica, Vol. 10, No. 13, pp. 173-169. DOI: 10.7592/ methis.v10i13.1309. Available at https://ojs.utlib.ee/index.php/methis/article/ view/1309/1258, last accessed on 15 July 2019.

Ojamaa, Triinu \& Valk, Aune 2008. Pilootuurimus kanadaeestlaste etnilise identiteedi ja muusika seostest. [Relationship Between Estonian-Canadians' Ethnic Identity and Music: A Pilot Study.] In: K. Labi (ed.) Paar sammukest XXIV: Eesti Kirjandusmuuseumi aastaraamat 2007. Tartu: Eesti Kirjandusmuuseumi Teaduskirjastus, pp. 59-85.

Parming, Tõnu 1978. Eestlased, intiimsus, armastus, abielu ja lahutused. [Estonians, Intimacy, Love, Marriage, and Divorces.] Välis-Eesti, 24 November, p. 4.

Parming, Tõnu 1979. Eros ja Esto. [Eros and Estonianness.] In: E. Klaar \& J. Maandi \& A. Reinson \& J. Seim (eds.) Metroo teine raamat. Stockholm: Metroo-trükk, pp. 32-53.

Pennar, Jaan \& Parming, Tõnu \& Rebane, P. Peter 1975. The Estonians in America 1627-1975: A Chronology \& Fact Book. Ethnic Chronology Series, No. 17. Dobbs Ferry, New York: Oceana Publications.

Qianqian Li 2015. Becoming an American: Rethinking the United States Naturalization Policy. In: Florian Kläger \& Klaus Stierstorfer (eds.) Diasporic Constructions of Home and Belonging. Berlin \& Boston: De Gruyter, pp. 315-330.

Rand, Walter 1978. Globaalne eestlus. [Global Estonianness.] Mana, Vol. 45, pp. 77-85. Available at https://www.digar.ee/arhiiv/et/perioodika/63444, last accessed on 14 May 2018.

Rakfeldt, Jaak 1978. Äärel olemine. [Being at the Border.] Aja Kiri, No. 4, pp. 27-30. Available at https://www.digar.ee/arhiiv/et/perioodika/36723, last accessed on 14 May 2018.

Rakfeldt, Jaak 2015. Home Environments, Memories, and Life Stories: Preservation of Estonian National Identity. Journal of Baltic Studies, Vol. 46, No. 4, pp. 511-542. https://doi.org/10.1080/01629778.2015.1075137.

Reeskens, Tim \& Wright, Matthew 2014. Host-Country Patriotism among European Immigrants: A Comparative Study of Its Individual and Societal Roots. Ethnic and Racial Studies, Vol. 37, No. 14, pp. 2493-2511. http://dx.doi.org/10.1080/01 419870.2013 .851397$.

Safran, William 1991. Diasporas in Modern Societies: Myth of Homeland and Return. Diaspora: A Journal of Transnational Studies, Vol. 1, No. 1, pp. 83-99. http:// dx.doi.org/10.1353/dsp.1991.0004.

Salasoo, Inno 1986. The Estonians in Australia. In: M.Cigler (ed.) The Baltic Peoples in Australia: Lithuanians, Latvians, Estonians. Australian Ethnic Heritage Series. Melbourne: AE Press, pp. 107-164.

Tauli, Valter (comp.) 1953. Eesti kultuurpoliitika sihtjooni. Juhtmõtteid eesti kultuuri taastamiseks vabal kodumaal: Esialgne kavand. [Directions of the Estonian Cultural Policy. Some Ideas about the Restoration of Estonian Culture in Free Homeland: Preliminary Plan.] Stockholm: Eesti Rahvusnõukogu Kultuurikomisjon.

Toona, Elin 1974. Sipelgas sinise kausi all. [The Ant under the Blue Bowl.] Lund: Eesti Kirjanike Kooperatiiv. 
Triinu Ojamaa

Valk, Aune \& Karu-Kletter, Kristel \& Drozdova, Marianna 2011. Estonian Open Identity: Reality and Ideals. Trames, Vol. 15, No. 1, pp. 33-59. Available at http://www. kirj.ee/18474/, last accessed on 14 May 2018. 